\title{
Breast Cancer pNO(mol+) TNM Finding v6 and v7
}

National Cancer Institute

\section{Source}

National Cancer Institute. Breast Cancer pNO(mol+) TNM Finding v6 and v7. NCI

Thesaurus. Code C48995.

Breast cancer with positive molecular findings by RT-PCR, but without histological or immunohistochemical evidence of regional lymph node involvement. (from AJCC 6th and 7th Ed.) 